\title{
Aplikasi beberapa jenis pupuk organik cair terhadap pertumbuhan dan produksi tanaman cabai rawit (Capsicum frutescens l.)
}

\author{
(Applications of some liquid organic fertilizers on growth and production of cayenne pepper \\ (Capsicum frutescens l.))
}

\author{
A. N. Fitriningtyas, Sutarno dan E. Fuskhah \\ Agroecotechnology, Faculty of Animal and Agricultural Sciences, Diponegoro University \\ Tembalang Campus, Semarang 50275 - Indonesia \\ Corresponding E-mail : asri.fn28@gmail.com
}

\begin{abstract}
ABSTRAK
Penelitian ini bertujuan untuk mengetahui jenis pupuk organik cair dan interval waktu pemberian yang tepat guna mendapatkan hasil pertumbuhan dan produksi tanaman cabai rawit yang baik. Penelitian menggunakan rancangan acak lengkap pola faktorial $4 \times 3$ dengan faktor pertama jenis pupuk P1: Urin kelinci, P2: Urin sapi, P3: Bio extrim, P4: Biofarm dan faktor kedua interval waktu pemberian pupuk T1: 5 hari sekali, T2: 10 hari sekali, T3: 15 hari sekali. Masing-masing perlakuan diulang sebanyak 3 kali. Analisis data yang digunakan yaitu analisis ragam (ANOVA) dan dilanjut dengan uji Duncan's Multiple Range Test (DMRT) taraf 5\%. Parameter yang diamati adalah tinggi tanaman, jumlah daun, jumlah buah per tanaman, dan berat buah per tanaman. Hasil penelitian menunjukkan bahwa pupuk Bio extrim memberikan hasil tertinggi pada semua parameter dan diikuti oleh pupuk urin kelinci. Interval waktu pemberian pupuk 5 hari sekali dapat meningkatkan tinggi tanaman cabai rawit.
\end{abstract}

Kata kunci: cabai rawit, pupuk organik cair, interval waktu pemberian

\begin{abstract}
This research aims to determine the suitable type of liquid organic fertilizers and the corrected application to maximize the growth and productions of cayenne pepper. This experiment used a completely randomized factorial design $4 \times 3$ with 3 replications. The first factor was the types of fertilizers P1: Rabbit urine, P2: Cow urine, P3: Bio extrim, P4: Biofarm and the second factor was the interval of fertilizer application T1: 5 days, T2: 10 days, T3: 15 days. The data analysis used analysis of variance (ANOVA) and continued with Duncan's Multiple Range Test (DMRT) of 5\%. The parameters of the observation were the height of plants, number of leaves, number of fruits, and weight of fruit per plant. The result shows that Bio extrim gave the highest result in all parameters and than followed by rabbit urine. The interval of 5 days fertilizer gave the best result on the parameters of plant's height.

Keywords: cayenne pepper, organic liquid fertilizer, interval of fertilizer aplication
\end{abstract}

\section{PENDAHULUAN}

Cabai rawit (Capsicum frutescens L.) merupakan tanaman yang termasuk dalam famili Solanaceae dan berasal dari Amerika Tengah dan Selatan. Cabai rawit merupakan jenis tanaman perdu yang memiliki kayu, bercabang dan tumbuh tegak. Kandungan zat-zat gizi pada cabai rawit meliputi kalori, protein, lemak, karbohidrat, mineral, vitamin, dan zat-zat yang berkhasiat untuk obat seperti capsaicin, bioflavonoid, dan minyak atsiri (Cahyono, 2003). Tanaman cabai rawit dapat tumbuh baik di dataran tinggi maupun dataran rendah dengan ketinggian 1-1.500 $\mathrm{m}$ dpl dan tumbuh optimal pada daerah dengan suhu 25$32^{\circ} \mathrm{C}$. Tanaman cabai rawit cocok ditanam di tempat terbuka dan tidak ternaungi dengan lama penyinaran 10-12 jam (Bastian, 2016).

Pupuk organik merupakan pupuk yang tersusun dari materi makhluk hidup yang diolah 
melalui proses pembusukan oleh bakteri pengurai. Berdasarkan bentuk fisiknya pupuk organik dibagi menjadi dua yaitu pupuk organik padat dan pupuk organik cair. Pupuk organik cair adalah larutan hasil dari pembusukan bahan-bahan organik yang berasal dari sisa tanaman, kotoran hewan dan manusia yang memiliki unsur hara lebih dari satu (Hadisuwito, 2012). Pupuk organik cair memiliki keuntungan yaitu mudah diaplikasikan, unsur hara yang terkandung di dalamnya lebih mudah diserap karena unsurnya sudah terurai, meningkatkan kualitas produk tanaman dan mengurangi penggunaan pupuk anorganik (Murniati dan Safriyani, 2012).

Urin kelinci mengandung unsur hara N P K dengan rata-rata $\mathrm{N} 1,20-1,90 \%$, $\mathrm{P} 0,29-0,55 \%$ dan $\mathrm{K} \quad 0,44-1,67 \%$. Kandungan ini lebih tinggi dibandingkan dengan urin hewan ternak yang lain seperti sapi, kambing dan domba (Azizah, 2017). Urin kelinci dapat bermanfaat memperbaiki struktur tanah, pupuk organik urin kelinci juga bermanfaat untuk pertumbuhan tanaman, herbisida, dan dapat mengendalikan hama penyakit, mengusir hama tikus, walang sangit dan serangga kecil pengganggu lainnya (Karo et al., 2014).

Urin sapi menjadi salah satu alternatif untuk meningkatkan ketersediaan, kecukupan, dan efisiensi serapan hara bagi tanaman yang mengandung mikroorganisme sehingga dapat mengurangi penggunaan pupuk anorganik dan meningkatkan hasil tanaman secara maksimal. Kandungan unsur hara N P K pada urin sapi yaitu $\mathrm{N} 0,52 \%, \mathrm{P} 0,01 \%$ dan $\mathrm{K}$ 0,56\% (Hadisuwito,
2012). Urin sapi juga mengandung zat pengatur tumbuh seperti auksin (Pangaribuan et al., 2017).

Pupuk Bio extrim mengandung nutrisi yang lengkap baik berupa unsur hara makro maupun unsur hara mikro, asam-asam amino dan hormon pertumbuhan seperti akusin, giberelin, sitokinin dan asam absisat, serta pestisida organik. Kandungan NPK pada pupuk Bio extrim yaitu N $0,22 \%, \mathrm{P}_{2} \mathrm{O}_{5} \quad 0,35 \%$ dan $\mathrm{K}_{2} \mathrm{O} 0,11 \%$. Bio extrim mengandung bakteri fiksasi N2 seperti Azosprillum sp dan Azotobacter sp, serta mengandung bakteri pelarut fosfat seperti Bacillus sp dan Pseudomonas sp (Sagala, 2011).

Biofarm merupakan pupuk dari hasil samping produksi jamu yang berbahan baku tanaman obat dan rempah-rempah. Kandungan hara NPK pada Biofarm yaitu N 0,16\%, P 0,37\% dan $\mathrm{K} \quad 0,2 \%$. Biofarm mengandung beberapa mikroorganisme seperti Azotobacter sp, Azosprillium sp, bakteri pelarut fosfat, Lactobacillus sp, Pseudomonas sp dan Selulotik sp (Arlingga, 2014).

Pada tanaman tomat pemberian pupuk urin kelinci berpengaruh nyata meningkatkan tinggi tanaman (Lestari, 2016). Pemberian pupuk bio urin sapi pada tanaman seledri mampu meningkatkan tinggi tanaman, jumlah daun dan panjang daun (Palenewen, 2014). Perlakuan fermentasi urin sapi 30 hari memiliki berat buah tomat pertanaman tertinggi yaitu seberat $124,88 \mathrm{~g}$ dibandingkan dengan perlakuan kontrol dan fermentasi 10 hari yaitu seberat $122,25 \mathrm{~g}$ dan 122,50 g (Chaniago et al., 2017). Tanaman kedelai yang diberi pupuk Bio extrim dapat

Tabel 1. Tinggi Tanaman Cabai Rawit pada Perlakuan Jenis Pupuk dan Interval Waktu Pemberian Pupuk yang Berbeda

\begin{tabular}{ccccc}
\hline \hline \multirow{2}{*}{ Jenis Pupuk } & \multicolumn{3}{c}{ Interval Waktu Pemberian Pupuk } & \multirow{2}{*}{ Rata-rata } \\
\cline { 2 - 3 } & 5 hari (T1) & 10 hari (T2) & 15 hari (T3) & \\
\hline & $--58,67$ & 56,33 & 51,67 & $55,56^{\mathrm{a}}$ \\
Urin Kelinci (P1) & 51,33 & 44,00 & 44,00 & $46,44^{\mathrm{b}}$ \\
Urin Sapi (P2) & 62,00 & 58,33 & 56,00 & $58,78^{\mathrm{a}}$ \\
Bio Extrim (P3) & 41,67 & 41,67 & 40,33 & $41,22^{\mathrm{b}}$ \\
Biofarm (P4) & $53,42^{\mathrm{a}}$ & $50,08^{\mathrm{b}}$ & $48,00^{\mathrm{b}}$ & \\
Rata-rata & & &
\end{tabular}

Superskrip yang berbeda pada kolom dan baris yang sama menunjukkan perbedaan yang nyata $(\mathrm{P}<0,05)$ 
meningkatkan tinggi tanaman dan jumlah polong (Tabah dan Sumihar, 2013). Pemberian berbagai konsentrasi pupuk Biofarm pada tanaman tomat dapat meningkatkan jumlah buah tomat (Wijaya et al., 2015). Pemberian pupuk Biofarm dengan dosis $2 \mathrm{ml} / \mathrm{ltr}$ air mampu memberikan hasil terbaik dibandingkan dengan dosis $0 \mathrm{ml} / \mathrm{ltr}$ air (kontrol) pada variabel umur berbunga, jumlah buah dan berat buah (Hasibuan, 2014).

Penelitian ini bertujuan untuk mengetahui jenis pupuk organik cair dan interval waktu pemberian yang tepat guna mendapatkan hasil pertumbuhan dan produksi tanaman cabai rawit yang baik.

\section{MATERI DAN METODE}

\section{Materi}

Penelitian telah dilaksanakan pada bulan Maret - Juli 2017 di lahan warga Jalan Tlogosari Utara, Tembalang, Semarang dan di Laboraturium Ekologi dan Produksi Tanaman, Fakultas Peternakan dan Pertanian, Universitas Diponegoro, Semarang. Materi yang digunakan antara lain bibit cabai rawit varietas Savana 320, pupuk kandang, pupuk organik cair (urin kelinci, urin sapi, Bio extrim dan Biofarm).

\section{Metode}

Penelitian dilakukan dengan tahapan persiapan alat dan bahan, pembuatan pupuk organik cair limbah urin, pengolahan media tanam, penanaman, perawatan, pengamatan parameter pertumbuhan, panen, serta pengamatan parameter produksi. Pembuatan pupuk organik cair limbah urin dilakukan dengan memfermentasi urin hewan ternak yang ditambahkan molase dan EM4 selama 14 hari ke dalam jerigen plastik (Huda, 2013). Persiapan media tanam dilakukan dengan menyiapkan polybag ukuran $40 \times 40 \mathrm{~cm}$, menimbang tanah dan pupuk kandang sapi sebagai pupuk dasar. Polybag diisi satu bibit cabai rawit. Penanaman dilakukan dengan melepas polybag kecil pada bibit dan langsung menanamnya. Perawatan dilakukan dengan menyiram tanaman setiap hari pada pagi dan sore hari, penyiangan gulma secara manual. Pemupukan dilakukan sesuai dengan perlakuan yang sudah ada. Panen dilakukan 97 hari setelah pindah tanam. Cabai rawit siap panen saat buahnya berwarna kuning kemerahan, buah dipetik beserta tangkainya.

Parameter pertumbuhan yang diamati yaitu 1) tinggi tanaman, 2) jumlah daun, sedangkan parameter produksi yang diamati yaitu 1) jumlah buah per tanaman, 2) panjang buah dan 3) berat buah per tanaman.

\section{Rancangan Percobaan dan Analisis Data}

Rancangan yang digunakan dalam penelitian adalah Rancangan Acak Lengkap (RAL) pola faktorial $4 \times 3$ dengan tiga kali ulangan. Faktor pertama adalah jenis pupuk organik cair $(\mathrm{P})$ yaitu urin kelinci (P1), urin sapi (P2), Bio extrim (P3), dan Biofarm (P4). Faktor kedua adalah perlakuan interval waktu pemberian (T) yaitu 5 hari sekali (T1), 10 hari sekali (T2), dan 15 hari sekali (T3). Analisis data dilakukan dengan menggunakan analisis ragam (ANOVA) dan dilanjutkan dengan

Tabel 2. Jumlah Daun Cabai Rawit pada Perlakuan Jenis Pupuk dan Interval Waktu Pemberian Pupuk yang Berbeda

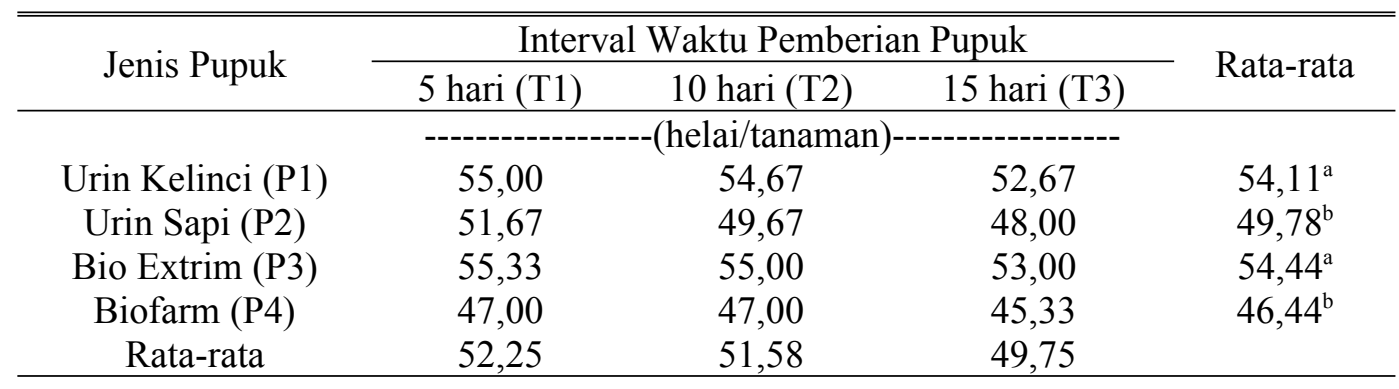

Superskrip yang berbeda pada kolom yang sama menunjukkan perbedaan yang nyata $(\mathrm{P}<0,05)$ 
uji Duncan's Multiple Range Test (DMRT) pada taraf 5\%.

\section{HASIL DAN PEMBAHASAN}

\section{Tinggi Tanaman}

Hasil analisis ragam menunjukkan bahwa tidak terdapat pengaruh interaksi antara perlakuan jenis pupuk dan interval waktu pemberian pupuk terhadap tinggi tanaman. Perlakuan jenis pupuk dan interval waktu pemberian pupuk masingmasing berpengaruh nyata $(\mathrm{P}<0,05)$ terhadap tinggi tanaman cabai rawit. Hasil uji Duncan's Multiple Range Test (DMRT) perlakuan jenis pupuk dan interval waktu pemberian pupuk pada tinggi tanaman disajikan pada Tabel 1 .

Hasil uji DMRT (Tabel 1) menunjukkan bahwa perlakuan interval waktu pemberian pupuk 5 hari sekali memiliki tinggi rata-rata $53,42 \mathrm{~cm}$ nyata lebih tinggi dibanding dengan interval waktu pemberian pupuk 10 hari sekali dan 15 hari sekali dengan hasil masing-masing 50,08 $\mathrm{cm}$ dan $48,00 \mathrm{~cm}$. Hal ini menunjukkan bahwa semakin seringnya waktu pemberian pupuk akan menyebabkan kandungan unsur hara pada tanaman juga semakin tinggi. Hal ini sesuai dengan pernyataan Silalahi (2013) yang menyatakan bahwa penyemprotan yang sering dilakukan menjadikan tanaman tumbuh dengan baik, karena unsur hara yang diterima oleh tanaman lebih banyak.

Tabel 1 menunjukkan jenis pupuk Bio extrim tidak berbeda nyata dengan pupuk urin kelinci dengan hasil masing-masing sebesar $58,78 \mathrm{~cm}$ dan
$55,56 \mathrm{~cm}$, namun berbeda nyata $(\mathrm{P}<0,05)$ lebih tinggi dengan jenis pupuk urin sapi dan Biofarm dengan hasil masing-masing sebesar 46,44 $\mathrm{cm}$ dan $41,22 \mathrm{~cm}$. Perlakuan jenis pupuk terhadap tinggi tanaman didapatkan hasil bahwa perlakuan jenis pupuk Bio extrim dan urin kelinci menunjukkan hasil rerata yang lebih tinggi dibandingkan dengan perlakuan jenis pupuk urin sapi dan Biofarm. Pupuk Bio extrim mengandung zat pengatur tumbuh berupa auksin yang berperan dalam pembelahan sel. Koentjoro (2008) menyatakan bahwa zat pengatur tumbuh auksin mempunyai kemampuan dalam mendukung terjadinya cell elongation (pemanjangan sel). Sedangkan urin kelinci mengandung unsur hara nitrogen lebih tinggi yaitu $1,9 \%$ dibandingkan jenis hewan ternak lainnya. Unsur hara nitrogen sangat berpengaruh terhadap pertumbuhan vegetatif tanaman dan dibutuhkan dalam jumlah besar. Segari et al. (2017) menyatakan bahwa nitrogen merupakan komponen utama dari berbagai substansi dalam tanaman, nitrogen juga dibutuhkan dalam jumlah relatif besar pada setiap pertumbuhan tanaman, khususnya pada tahap pertumbuhan vegetatif, pembentukan tunas, perkembangan batang dan daun.

\section{Jumlah Daun}

Hasil analisis ragam menunjukkan bahwa tidak terdapat pengaruh interaksi antara perlakuan jenis pupuk dan interval waktu pemberian pupuk terhadap jumlah daun. Perlakuan jenis pupuk masing-masing berpengaruh nyata $(\mathrm{P}<0,05)$ terhadap jumlah daun cabai rawit. Hasil uji

Tabel 3. Jumlah Buah Cabai Rawit per Tanaman pada Perlakuan Jenis Pupuk dan Interval Waktu Pemberian Pupuk yang Berbeda

\begin{tabular}{ccccc}
\hline \hline \multirow{2}{*}{ Jenis Pupuk } & \multicolumn{3}{c}{ Interval Waktu Pemberian Pupuk } & \multirow{2}{*}{ Rata-rata } \\
\cline { 2 - 3 } & 5 hari (T1) & 10 hari (T2) & 15 hari (T3) & \\
\hline Urin Kelinci (P1) & ------------------- & \multirow{2}{*}{$6,56^{\mathrm{b}}$} \\
Urin Sapi (P2) & 8,00 & 6,00 & 5,67 & $4,44^{\mathrm{b}}$ \\
Bio Extrim (P3) & 5,00 & 4,67 & 3,67 & $10,56^{\mathrm{a}}$ \\
Biofarm (P4) & 12,67 & 10,00 & 9,00 & $4,78^{\mathrm{b}}$ \\
Rata-rata & 5,33 & 4,67 & 4,33 & \\
\hline
\end{tabular}

Superskrip yang berbeda pada kolom yang sama menunjukkan perbedaan yang nyata $(\mathrm{P}<0,05)$ 
Duncan's Multiple Range Test (DMRT) perlakuan jenis pupuk dan interval waktu pemberian pupuk pada jumlah daun disajikan pada Tabel 2 .

Hasil uji lanjut DMRT (Tabel 2) menunjukkan bahwa perlakuan jenis pupuk Bio extrim tidak berbeda nyata dengan pupuk urin kelinci dengan hasil masing-masing sebesar 54,44 helai/tanaman dan 54,11 helai/tanaman, namun berbeda nyata $(\mathrm{P}<0,05)$ lebih tinggi dengan jenis pupuk urin sapi dan Biofarm dengan hasil masingmasing sebesar 49,78 helai/tanaman dan 46,44 helai/tanaman. Hal ini menunjukkan bahwa jenis pupuk Bio extrim dan urin kelinci dapat meningkatkan jumlah daun tanaman cabai rawit. Pupuk Bio extrim mengandung mikroorganisme yang dapat mempengaruhi kandungan unsur hara dalam tanah salah satunya adalah bakteri pelarut fosfat. Adanya aktivitas mikroorganisme dapat meningkatkan ketersediaan unsur hara untuk tanaman sehingga dapat membantu proses pertumbuhan tanaman. Hedraswari (2017) menyatakan bahwa semakin banyak unsur hara yang diperoleh tanaman yang berasal dari aktivitas mikroorganisme maka pertumbuhan tinggi tanaman akan semakin baik dan jumlah daun yang dihasilkan semakin banyak. Pupuk Bio Extrim mengandung beberapa mikroorganisme yang dapat meningkatkan kandungan unsur hara yang dibutuhkan tanaman. Sagala et al. (2011) menyatakan bahwa pupuk Bio Extrim memiliki komposisi jenis mikroba seperti Rhizobium sp, Azospirillium sp, Azotobacter sp, Bacillus sp, Salmonella, dan E. Colli yang berperan meningkatkan unsur hara yang dibutuhkan tanaman, menghasilkan zat perangsang tumbuh dan memacu percepatan proses pengeluaran akar. Permatasari dan Nurhidayati (2014) menambahkan bahwa bakteri pelarut fosfat (Bacillus megaterium dan Bacillus subtilis) dapat memberikan pengaruh pada pertumbuhan tanaman cabai rawit (Capsicum frutescens L.) yang mampu meningkatkan tinggi tanaman, jumlah daun, dan berat buah.

Urin kelinci mengandung unsur nitrogen yang tinggi yaitu $1,9 \%$ dibandingkan dengan jenis pupuk yang lainnya. Nitrogen merupakan unsur utama dalam pertumbuhan vegetatif tanaman. Lestari (2016) menyatakan bahwa pemberian unsur nitrogen yang semakin meningkat akan merangsang pertumbuhan vegetatif tanaman, khususnya jumlah daun dan jumlah anakan tanaman. Setiawan (2007) menambahkan bahwa nitrogen digunakan untuk pertumbuhan tunas, batang dan daun, fosfor digunakan untuk merangsang pertumbuhan akar, buah, dan biji. Sedangkan kalium digunakan untuk meningkatkan ketahanan tanaman terhadap serangan hama dan penyakit.

\section{Jumlah Buah per Tanaman}

Hasil analisis ragam menunjukkan bahwa tidak terdapat pengaruh interaksi antara perlakuan jenis pupuk dan interval waktu pemberian pupuk terhadap jumlah buah per tanaman. Perlakuan jenis pupuk masing-masing berpengaruh nyata $(\mathrm{P}<0,05)$ terhadap jumlah buah per tanaman. Hasil uji Duncan's Multiple Range Test (DMRT) perlakuan jenis pupuk dan interval waktu

Tabel 4. Berat Buah Cabai Rawit per Tanaman pada Perlakuan Jenis Pupuk dan Interval Waktu Pemberian Pupuk yang Berbeda

\begin{tabular}{|c|c|c|c|c|}
\hline \multirow{2}{*}{ Jenis Pupuk } & \multicolumn{3}{|c|}{ Interval Waktu Pemberian Pupuk } & \multirow{2}{*}{ Rata-rata } \\
\hline & 5 hari (T1) & 10 hari (T2) & 15 hari $(\mathrm{T} 3)$ & \\
\hline & \multicolumn{3}{|c|}{----------------(g/tanaman)----------------- } & \\
\hline Urin Kelinci (P1) & 17,95 & 14,70 & 9,51 & $14,05^{\mathrm{a}}$ \\
\hline Urin Sapi (P2) & 6,95 & 6,14 & 4,60 & $5,89^{\mathrm{b}}$ \\
\hline Bio Extrim (P3) & 18,01 & 14,84 & 10,87 & $14,58^{\mathrm{a}}$ \\
\hline Biofarm (P4) & 8,24 & 6,92 & 4,83 & $6,66^{\mathrm{b}}$ \\
\hline Rata-rata & 12,79 & 10,65 & 7,45 & \\
\hline
\end{tabular}

Superskrip yang berbeda pada kolom yang sama menunjukkan perbedaan yang nyata $(\mathrm{P}<0,05)$ 
pemberian pupuk pada jumlah buah per tanaman disajikan pada Tabel 3.

Hasil uji lanjut DMRT (Tabel 3) menunjukkan bahwa perlakuan jenis pupuk Bio extrim dengan hasil rerata 10,56 buah berbeda nyata $(\mathrm{P}<0,05)$ lebih tinggi dibandingkan dengan urin kelinci, urin sapi dan Biofarm dengan hasil rerata masing-masing 6,56 buah, 4,44 buah dan 4,7 buah. Hal ini menunjukkan bahwa pemberian pupuk Bio extrim dapat meningkatkan jumlah buah cabai rawit per tanaman. Bio extrim mengandung zat pengatur tumbuh (ZPT) giberelin yang dapat mengurangi gugurnya bunga yang akan mempengaruhi jumlah buah. Giberelin dapat menurunkan jumlah bunga gugur, jumlah buah gugur, meningkatkan jumlah bunga dan jumlah panen. Hal ini sesuai dengan pendapat Yeni dan Mulyani (2012) yang menyatakan bahwa giberelin akan merangsang dan mempertinggi prosentase timbulnya bunga dan buah karena giberelin dapat merangsang pembungaan serta dapat mengurangi gugurnya bunga dan buah sebelum waktunya. Bio extrim mengandung ZPT seperti auksin, giberelin dan asam absisat yang dapat mempengaruhi produksi buah cabai rawit. Zat pengatur tumbuh (ZPT) yang terkandung didalam pupuk dapat mempengaruhi pertumbuhan dan perkembangan tanaman. Antonius dan Rahmi (2016) menyatakan bahwa zat pengatur tumbuh seperti giberelin, asam indol asetat, kinetin dan zeatin dapat mendorong proses pertumbuhan dan perkembangan tanaman.

\section{Berat Buah Cabai Rawit}

Hasil analisis ragam menunjukkan bahwa tidak terdapat pengaruh interaksi antara perlakuan jenis pupuk dan interval waktu pemberian pupuk terhadap berat buah cabai rawit. Perlakuan jenis pupuk masing-masing berpengaruh nyata $(\mathrm{P}<0,05)$ terhadap berat buah cabai rawit. Hasil uji Duncan's Multiple Range Test (DMRT) perlakuan jenis pupuk dan interval waktu pemberian pupuk pada tinggi tanaman disajikan pada Tabel 4.

Hasil uji DMRT (Tabel 4) menunjukkan bahwa menunjukkan bahwa perlakuan jenis pupuk Bio extrim tidak berbeda nyata dengan pupuk urin kelinci dengan hasil masing-masing sebesar 14,58 $\mathrm{g} /$ tanaman dan 14,05 g/tanaman, namun berbeda nyata $(\mathrm{P}<0,05)$ lebih berat dibandingkan dengan jenis pupuk urin sapi dan Biofarm dengan hasil masing-masing sebesar 5,89 g/tanaman dan 6,66 $\mathrm{g} /$ tanaman. Hal ini menunjukkan bahwa pupuk
Bio extrim dan urin kelinci mampu meningkatkan secara signifikan berat buah cabai rawit per tanaman dibandingkan urin sapi dan Biofarm. Kandungan NPK yang tinggi pada pupuk urin kelinci mampu meningkatkan ketersediaan unsur hara NPK pada tanaman cabai sehingga dapat memacu pertumbuhan dan perkembangan tanaman cabai. Antonius dan Rahmi (2016) menyatakan bahwa tanaman akan tumbuh dengan subur apabila unsur hara yang dibutuhkannya tersedia cukup dan unsur hara tersebut tersedia dalam bentuk yang diserap oleh tanaman. Bio extrim mengandung zat pengatur tumbuh (ZPT) berupa giberelin yang mampu merangsang pembungaan sekaligus mengurangi jumlah gugurnya bunga sengingga dapat meningkatkan hasil panen. Hal ini sesuai dengan pendapat Yeni dan Mulyani (2012) yang menyatakan bahwa giberelin akan merangsang dan mempertinggi persentase timbulnya bunga dan buah karena giberelin dapat merangsang pembungaan serta dapat mengurangi gugurnya bunga dan buah sebelum waktunya. Bio extrim mengandung bakteri pelarut fosfat (Bacillus sp) yang berfungsi sebagai penyedia unsur hara dalam tanah sehingga dapat tersedia untuk tanaman. Hal ini sesuai dengan pendapat Rahman et al. (2015) yang menyatakan bahwa bakteri pelarut fosfat (Bacillus megaterium dan Bacillus subtilis) diketahui dapat memberikan pengaruh pada pertumbuhan tanaman cabai yang mampu meningkatkan tinggi tanaman, jumlah daun dan berat buah.

Pupuk urin kelinci juga mengandung unsur hara seperti N P K yang lebih tinggi dibandingkan dengan pupuk urin sapi. Melda et al. (2017) menyatakan bahwa pada percobaanya pupuk urin kelinci juga memberikan jumlah buah dan berat buah tomat yang terbaik dibandingkan dengan perlakuan kontrol, urin sapi dan urin kambing karena urin kelinci mengandung $\mathrm{N}, \mathrm{P}, \mathrm{K}$ yang tinggi. Lestari (2016) menambahkan kandungan $\mathrm{N}, \mathrm{P}$ dan $\mathrm{K}$ yang tinggi pada urin kelinci dapat mencukupi nutrisi pada tanaman, sehingga akan menghasilkan buah yang lebih besar.

\section{KESIMPULAN}

Berdasarkan hasil penelitian dapat disimpulkan bahwa pupuk Bio extrim menunjukkan hasil tertinggi pada parameter tinggi 
tanaman, jumlah daun, jumlah buah per tanaman dan berat buah per tanaman dan diikuti oleh jenis pupuk urin kelinci. Perlakuan interval waktu pemberian pupuk 5 hari sekali dapat meningkatkan tinggi tanaman cabai rawit. Pupuk urin kelinci dapat menggantikan pupuk Bio extrim sebagai pupuk produksi pabrik. Pupuk urin kelinci nyata dapat meningkatkan pertumbuhan dan produksi tanaman cabai rawit sama seperti pupuk Bio extrim, namun dilihat dari segi harga pupuk urin kelinci lebih terjangkau serta bahan mudah didapat.

\section{DAFTAR PUSTAKA}

Antonius., dan A. Rahmi. 2016 Pengaruh pemberian pupuk NPK DGW Compaction dan POC Ratu Biogen terhadap pertumbuhan dan hasil tanaman cabai rawit (Capsicum frutescent L.) hibrida F-1 varietas Bhaskara. J. Agrivor 17 (1): 15-23.

Arlingga, B., A. Syakur, dan H. Mas'ud. 2014. Pengaruh presentase naungan dan dosis pupuk organik cair terhadap pertumbuhan tanaman seledri (Apium graveolens L.). J. Agrotekbis 2 (6): 611-619.

Azizah, N. 2017. Pengaruh Jenis Dekomposer dan Lama Fermentasi terhadap Kualitas Pupuk Cair (Biourine) Kelinci. Skripsi. Universitas Hasanuddin. Makasar.

Bastian. 2016. Identifikasi Karakter Beberapa Varietas Cabai (Capsicum annum L.) Introduksi di Rumah Kaca. Skripsi. Universitas Lampung. Bandar Lampung.

Cahyono, B. 2003. Cabai Rawit, Teknik Budi Daya dan Analisis Usaha Tani. Kanisius. Yogyakarta.

Chaniago, N., Safrudin, dan D. Kurniawan. 2017. Respon pertumbuhan dan produksi tanaman tomat (Lycopersicum esculentum Mill) terhadap pemberian pupuk kandang dan fermentasi urin sapi. J. Penelitian Pertanian Bernas 13 (1): 23-29.

Hadisuwito, S. 2012. Membuat Pupuk Organik
Cair. Agromedia Pustaka. Jakarta.

Hasibuan, S. 2014. Respon pemberian konsentrasi pupuk Herbafarm dan POC keong mas terhadap pertumbuhan dan produksi tanaman mentimun (Cucumis sativus L.). J. Bernas 13 (2): 59-64.

Hendraswari, N. 2017. Penambahan Konsorsium Mikroba Non Simbiosis dan Mikoriza Arbuskular sebagai Pupuk Hayati untuk Meningkatkan Pertumbuhan dan Produktivitas Tanaman Gingseng Jawa (Talium paniculatum). Skripsi. Universitas Nusantara PGRI Kediri. Kediri.

Huda, M. K. 2013. Pembuatan Pupuk Organik Cair dari Urin Sapi Sapi dengan Aditif Tetes Tebu (Molasses) Metode Fermentasi. Skripsi. Universitas Negeri Semarang. Semarang.

Karo, B., A. E. Marpaung, dan A. Lasmono. 2014. Efek Tehnik Penanaman dan Pemberian Urin Kelinci terhadap Pertumbuhan dan Produksi Tanaman Kentang Granola (Solanum tuberosum L.). Prosding Seminar Nasional Sains dan Teknologi Pertanian. Bandar Lampung.

Koentjoro, Y. 2008. Aplikasi pemberian zat pengatur tumbuh pada tanaman cabai kecil yang ditanam di musim hujan. J. Pertanian Mapeta 10 (3): 170-178.

Lestari, E. P. 2016. Pengaruh Beberapa Jenis Urin terhadap Pertumbuhan dan Hasil Beberapa Varietas Tomat (Lycopersicum esculentum Mill.). Skripsi. Universitas PGRI Yogyakarta. Yogyakarta.

Melda, Y. S., L. Setyobudi, dan Y. Sugito. 2017. Pengaruh dosis pupuk urin kelinci terhadap pertumbuhan dan hasil beberapa varietas tomat. J. Produksi Tanaman 5 (1): 132-139.

Murniati, N., dan E. Safriyani. 2012. Pemanfaatan urine sapi sebagai pupuk organik cair untuk meningkatkan produktivitas tanaman selada. J. Agro Silampari 2 (1): 9-17. 
Palenewen, E. 2014. Pengaruh urin sapi sebagai pupuk cair terhadap pertumbuhan dan hasil tanaman seledri (Apium graveolens L.) sebagai penunjang matakuliah botani tingkat tinggi. J. Bioedukasi 2 (2): 213-220.

Pangaribuan, D. H., Sarno, dan M. C. Kurniawan. 2017. Pengaruh pupuk cair urine sapi terhadap pertumbuhan dan produksi tanaman jagung manis (Zea mays L.). J. Metamorfosa 4 (2): 202-209.

Permatasari, A. D., dan T. Nurhidayati. 2014. Pengaruh inokulan bakteri penambat nitrogen, bakteri pelarut fosfat dan mikoriza asal desa Condro, Lumajang, Jawa Timur terhadap pertumbuhan tanaman cabai rawit. J. Sains dan Seni Pomits 3 (2): 44-48.

Rahman, R., M. Anshar, dan Bahrudin. 2015. Aplikasi bakteri pelarut fosfat, bakteri penambat nitrogen dan mikoriza terhadap pertumbuhan tanaman cabai. J. Agrotekbis 3 (3): 326-328.

Sagala, A. D., S. Utami, dan A. S. Damanik. 2011. Respon pertumbuhan bibit kakao (Theobroma cacao L.) dengan pemberian pupuk hayati Bio Extrim pada berbagai media tanaman. J. Agrium 17 (1): 7-11.
Segari, A., H. Rianto, dan Y. E. Susilowati. 2017. Pengaruh macam media dan dosis urin kelinci terhadap hasil tanaman seledri. J. Ilmu Pertanian Tropika dan Subtropika 2 (1): 1-4.

Setiawan, A. I. 2007. Memanfaatkan Kotoran Ternak. Penebar Swadaya. Jakarta.

Silalahi, S. G. 2013. Pengaruh Konsentrasi Urine Sapi dengan Dua Interval Penyemprotan terhadap Pertumbuhan Tanaman Sawi Hijau (Brassica juncea L.). Skripsi. Universitas Islam Negeri Sultan Syarif Kasim Riau. Pekanbaru.

Tabah, S., dan T. Sumihar. 2013. Kajian penggunaan pupuk hayati Bio extrim dan NPK mutiara pada pertanaman kedelai (Glycine max (L.) Merril). J. LPPM Wanaha Inovasi 2 (2): 86-101.

Wijaya, A. S., M. N. Sangadji, dan Muhardi. 2015. Produksi dan kualitas produksi buah tomat yang diberi berbagai konsentrasi pupuk organik cair. J. Agrotekbis 3 (6): 689-696.

Yeni, T., dan Mulyani. 2014. Pengaruh induksi giberelin terhadap pertumbuhan dan produksi tanaman cabai merah (Capsicum annum L.) sebagai sumber belajar biologi. J. Pendidikan Biologi 5 (1): 1-10. 